\title{
Electrocardiographic study in the American Quarter Horse breed
}

\author{
[Estudo eletrocardiográfico de equinos da raça Quarto de Milha] \\ M.M. Mantovani ${ }^{1}$, S.A. Tsuruta $^{2}$, R.A.L. Muzzi ${ }^{1}$, T. Machado ${ }^{2}$, M.F.S. Pádua ${ }^{2}$, C. Coimbra ${ }^{2}$, \\ L.A.L. Muzzi ${ }^{1}$, J.O. Jacomini ${ }^{2}$ \\ ${ }^{1}$ Universidade Federal de Lavras - Lavras, MG \\ ${ }^{2}$ Universidade Federal de Uberlândia - Uberlândia, MG
}

\begin{abstract}
An evaluation of the electrocardiographic profile of 50 clinically healthy Quarter Horses, with ages ranging from six months to 28 years old, 34 females and 16 males, was performed. Heart rate has not decreased with age, and duration of the QRS complex increased with the growth of the animal. The amplitude of the S and T1 waves were higher in male subjects than in female Quarter Horses.
\end{abstract}

Keywords: arrhythmias, equine, electrocardiogram, heart diseases, cardiovascular function

\section{RESUMO}

Avaliou-se o perfil eletrocardiográfico de 50 equinos da raça Quarto de Milha, clinicamente sadios, com idades variando de seis meses a 28 anos, sendo 34 fêmeas e 16 machos. A frequência cardíaca não diminuiu com a idade, e a duração do complexo QRS aumentou ao longo do crescimento do animal. A amplitude das ondas $S$ e $T_{l}$ foram maiores nos indivíduos machos do que nas fêmeas da raça Quarto de Milha.

Palavras-chave: arritmias, equinos, eletrocardiograma, doenças cardíacas, função cardiovascular

\section{INTRODUCTION}

The electrocardiogram (ECG) is an important diagnostic method in the recognition of various arrhythmias and in assessing the evolution of heart diseases (Belgrave, 1990; Reef, 1998). However, the use of electrocardiography still raises questions because the orientation, amplitude and duration of the ECG waves varies in different breeds of horses within the same race, and depending on the age and sex of the animal (Fernandes et al., 2004; Diniz et al., 2008).

Approximately $30 \%$ of the incidence of arrhythmias in healthy equines is considered to be physiological (Robertson, 1992), but incidence of pathological arrhythmia can cause poor athletic performance (Mitten, 1996). Some arrhythmias can be recognized using auscultation, but can only properly be confirmed by electrocardiography (Verheyen et al., 2010).

The physiological arrhythmias usually considered in horses are first and second degree atrioventricular block (AVB), wandering pacemaker and sinus bradycardia. Atrial and ventricular premature complexes, second degree AVB, advanced third degree AVB and atrial fibrillation arrhythmias can lead to a reduction in physical performance (Diniz et al., 2011).

Electrocardiographic characteristics have been evaluated in several breeds of horses such as the Mangalarga Marchador (Diniz et al., 2008), Thoroughbred (Fernandes et al., 2004) and Andaluz (Ayala et al., 1995), but not in the American Quarter Horse.

The American Quarter Horse is a breed that originated in the United States between the XVII

Recebido em 7 de junho de 2012

Aceito em 2 de julho de 2013

E-mail: matheus2mvet@gmail.com 
and XVIII centuries, and was introduced in Brazil in 1950. It is widely used in various competitive sports such as team roping, trail and barrel racing (Cintra, 2011).

The cardiovascular function can vary depending on the features and functions imposed in different breeds. This study aimed to describe both the electrocardiographic profile of the American Quarter Horse, comparing it to current standards, and the influence of sex and age on the electrocardiogram.

\section{MATERIAL AND METHODS}

For this study, fifty healthy horses of the American Quarter Horse breed were evaluated; comprising 34 females (68\%) and 16 males $(32 \%)$ aged from six months to 28 years. The animals were divided into three groups according to their age: group 1 included animals up to three years $(n=19)$; group 2 , animals more than three and less than 10 years $(n=16)$; and group 3, animals older than 10 years $(n=15)$. All animals underwent a general physical examination and animals with any disease were excluded from the study.

Electrocardiographic tracings were obtained for 60 seconds using apparatus of the C10 TEB system composed of a 12-channel digital electrocardiograph ECGPC Veterinary and Software Version 2.27. Bipolar derivations I, II and III and an increased unipolar aVR, aVL and $\mathrm{aVF}$ were recorded. Recordings were made with the animals in a standing position, at a speed $25 \mathrm{~mm} / \mathrm{se}$ sensitivity of $1 \mathrm{~cm}=1 \mathrm{mV}$.

The arrangement of the electrode system followed the bipolar base peak described in Young (2004), being fixed to the skin by means of metallic conductors such as "crocodile clips" and moistened with alcohol and gel.

In lead DII, the amplitude and duration of $\mathrm{P}$ waves, QRS complex and $\mathrm{T}$ wave were calculated. The duration of the PR interval, QRS complex, QT interval and ST segment levelling was calculated too. Three to five consecutive cardiac cycles were measured. The cardiac frequency in beats per minute (bpm) and heart rate were both determined.
The mean, standard deviation, and maximum and minimum values for the numeric variables, amplitude and duration of the waves, QRS complex and intervals, and the heart rate were calculated. Statistical analyses were performed using the software GrafPad InStatTM. The results were submitted to ANOVA $(p \leq 0.05)$ and Tukey post hoc tests or Student's $\mathrm{T}$ tests for comparison of means.

\section{RESULTS AND DISCUSSION}

Sinus rhythm and sinus tachycardia rhythms were those most frequently found, in $32 \%$ of cases. Sinus rhythm, according to the literature, is most often found in horses (Patteson, 1996; Fernandes et al., 2004; Diniz 2011). However, in contrast to the findings of Diniz (2008) for Mangalarga horses and Fernandes (2004) for thoroughbred race horses, presence of sinus tachycardia was higher in the present study.

Sinus tachycardia is often considered a rhythm, which may be physiological when associated with pain, exercise or excitement (Young, 2004). The stress to the animals must be considered when testing, because they may be frightened by the placement of the electrodes, therefore extending the time taken to return to normal condition. This was the probable cause of the increased frequency of sinus tachycardia in horses in our study compared to other studies.

In this study, sinus rhythm with wandering pacemaker rhythm was the second most frequently detected (20\%), and the presence of sinus tachycardia with wandering pacemaker was observed in $12 \%$ of the animals. Grade 2 atrioventricular block was found at low frequency $(4 \%)$, and was considered to be a clinical finding. Most authors agree that the wandering pacemaker, first and second degree atrioventricular blocks and sinoatrial block (sinus arrest) are all arrhythmias that are physiological in horses, some being influenced by high vagal tone, and disappearing with exercise (King et al., 1994; Mitten, 1996).

According to Raekallio (1992), the wandering pacemaker may be present in $30 \%$ of healthy horses when at rest, while the second degree AV block may be present in $15-18 \%$ of horses. The low frequency of this arrhythmia can be explained by the fact that animal studies are not 
being physically conditioned at the time of the study.

The mean values, standard deviation, maximum point and minimum point of the variables for heart rate, amplitude and duration of $\mathrm{P}$ wave, duration of the PR interval, QRS complex duration and QT interval duration, are shown in Table 1.

Table 1. Mean values, standard deviation (SD), maximum and minimum heart rate, duration of the waves and intervals of the electrocardiogram in lead II of American Quarter Horse

\begin{tabular}{lcccc}
\hline Parameter & Mean & Standart deviation & $\begin{array}{c}\text { Maximum } \\
\text { values }\end{array}$ & Minimum values \\
\hline Heart rate (bpm) & 52.62 & \pm 13.34 & 29.00 & 84.00 \\
P wave (ms) & 137.44 & \pm 24.61 & 190.00 & 87.00 \\
PR Interval (ms) & 266.04 & \pm 42.89 & 353.00 & 170.00 \\
QRS Complex (ms) & 123.44 & \pm 19.62 & 157.00 & 83.00 \\
QT Interval (ms) & 445.40 & \pm 59.40 & 563.00 & 323.00 \\
\hline
\end{tabular}

The average heart rate was found over the range described by Fregin (1992) for adult horses at rest, and varied from 24 to $50 \mathrm{bpm}$, which is higher than found in Mangalarga (Diniz, 2008) and Andaluz (Ayala et al., 1995) horses, and in horses when jumping (Diniz, 2011). This probably occurred because the most prevalent pace in the sample was the sinus tachycardia.

The results are within the patterns described by Patteson (1996), and are partly different to the results described by Ayala et al. (1994) for the breeds of Andalusian and Mangalarga horses (Vincenzi et al., 2000; Diniz, 2008) based on the same system of apex-base bipolar. Andalusian and Mangalarga Marchador horse breeds differ in their physical conformation when compared to American Quarter Horses, which could explain the small differences found between the durations and complexity of the waves. Thus, it is considered that in the context of this study, race was not a variable affecting these electrocardiographic parameters.

The $\mathrm{P}$ and $\mathrm{T}$ waves were observed in $100 \%$ of the traces. In the case of $\mathrm{P}$ waves, 37 were forked in the traces $(74 \%)$, single in $10(20 \%)$, and three were biphasic $(6 \%)$. The $\mathrm{T}$ wave was positive in six animals (12\%), negative in 19 (38\%) and biphasic in $25(50 \%)$. This distribution for waves is consistent with the pattern described by Patteson (1996) for this derivation, and was similar to that of other breeds.

The $\mathrm{T}$ wave may have different conformations in horses at rest, even with spontaneous changes in their registers (Patteson, 1996), but this was not observed in any of the traces that were analysed.
The amplitudes of the waves $\mathrm{P}, \mathrm{P} 1, \mathrm{P} 2, \mathrm{R}, \mathrm{S}, \mathrm{T}+$ and $\mathrm{T}$ - are described in Table 2. No Q wave was observed in any electrocardiographic tracing; $\mathrm{R}$ waves were observed in $62 \%$ of strokes and $\mathrm{S}$ and $\mathrm{T}$ waves in $100 \%$. The ST-T interval presented horizontal depression in $84 \%$ of registers. These results are different, in part, to those obtained by Ayala et al. (1994), who reported an average $\mathrm{R}$ wave amplitude of 0.321 $\mathrm{mV}$; S, $1.40 \mathrm{mV}$; T+, $0.55 \mathrm{mV}$; T-, $0.92 \mathrm{mV}$; and for ST-T interval, an elevation of $0.252 \mathrm{mV}$. These authors reported no $\mathrm{Q}$ waves in the tracings, unlike Diniz et al. (2008) who observed the presence of $\mathrm{Q}$ waves in equine Mangalarga Marchador.

In relation to sex (Table 3), there was a significant difference in the amplitude of the wave and the $S$ wave T1, a point also verified by Diniz et al. (2008) in their study of the Mangalarga, but dissimilar to results reported by Vincenzi et al. (2000) for the same breed.

Heart rate did not differ with ages (Table 4), despite a decrease of this characteristic having been observed with growth in thoroughbred (Fernandes et al., 2004) and Andalusian (Ayala, 1995) breeds.

There was no difference between ages when considering the duration of $\mathrm{P}$ waves, PR interval, $\mathrm{R}$ wave amplitude, the $\mathrm{S}$ wave amplitude and QT interval, a result similar to other authors' findings (Vincenzi et al., 2000). However, the duration of the QRS complex varied among ages and was higher in older than younger animals (Table 4). 


\section{Mantovani et al.}

Table 2. Mean values, standard deviation (SD), maximum and minimum height $(\mathrm{mV})$, the waves of the electrocardiogram in lead II of American Quarter Horses

\begin{tabular}{lcccc}
\multicolumn{1}{c}{ Parameter } & Mean & $\begin{array}{c}\text { Standart } \\
\text { deviation }\end{array}$ & $\begin{array}{c}\text { Maximum } \\
\text { value }\end{array}$ & $\begin{array}{c}\text { Minimum } \\
\text { value }\end{array}$ \\
\hline P wave & 0.33 & \pm 0.08 & 0.60 & 0.17 \\
$\mathrm{P}_{1}$ +wave & 0.19 & \pm 0.11 & 0.60 & 0.06 \\
$\mathrm{P}_{2}$ +wave & 0.32 & \pm 0.08 & 0.60 & 0.12 \\
$\mathrm{R}$ wave & 0.19 & \pm 0.29 & 1.69 & 0.04 \\
S wave & 1.75 & \pm 0.57 & 3.13 & 0.91 \\
$\mathrm{~T}_{1}$ wave & 0.64 & \pm 0.34 & 1.50 & 0.05 \\
$\mathrm{~T}_{2}$ wave & 0.34 & \pm 0.28 & 1.47 & 0.09 \\
ST segment & 0.24 & \pm 0.12 & 0.88 & 0.10 \\
\hline
\end{tabular}

Table 3. Mean, standard deviation and results of statistical analysis of the electrocardiographic characteristics of American Quarter Horses by gender

\begin{tabular}{lccc}
\hline Parameter & Male & Female & $\mathrm{P}$ \\
\hline Heart rate $(\mathrm{bpm})$ & $48 \pm 11$ & $54 \pm 13$ & 0.113 \\
P wave duration $(\mathrm{ms})$ & $145.00 \pm 23.22$ & $133.88 \pm 24.770$ & 0.137 \\
$\mathrm{P}$ wave height $(\mathrm{mV})$ & $0,32 \pm 0,06$ & $0,33 \pm 0,09$ & 0,884 \\
$\mathrm{P}_{1}$ wave height $(\mathrm{mV})$ & $0.17 \pm 0.07$ & $0.20 \pm 0.13$ & 0.345 \\
$\mathrm{P}_{2}$ wave height $(\mathrm{mV})$ & $0.32 \pm 0.06$ & $0.32 \pm 0.09$ & 0.985 \\
PR interval $(\mathrm{ms})$ & $281.69 \pm 34.75$ & $258.68 \pm 44.81$ & 0.076 \\
QRS complex duration $(\mathrm{ms})$ & $117.06 \pm 18.28$ & $126.44 \pm 19.76$ & 0.115 \\
$\mathrm{R}$ wave height $(\mathrm{mV})$ & $0.18 \pm 0.12$ & $0.19 \pm 0.33$ & 0.851 \\
$\mathrm{~S}$ wave height $(\mathrm{mV})$ & $2.00 \pm 0.58$ & $1.63 \pm 0.54$ & 0.036 \\
QT interval duration $(\mathrm{ms})$ & $467.94 \pm 63.88$ & $434.79 \pm 54.97$ & 0.065 \\
$\mathrm{~T}_{1}$ wave height $(\mathrm{mV})$ & $0.80 \pm 0.38$ & $0.538 \pm 0.27$ & 0.01 \\
$\mathrm{~T}_{2}$ wave height $(\mathrm{mV})$ & $0.28 \pm 0.22$ & $0.37 \pm 0.29$ & 0.435 \\
ST segment deviation $(\mathrm{mV})$ & $0.24 \pm 0.08$ & $0.23 \pm 0.13$ & 0.974 \\
\hline
\end{tabular}

$\mathrm{p}<0,05$ : significant statistical difference in $\mathrm{t}$ Student test

Table 4. Mean, standard deviation and results of statistical analysis of the electrocardiographic characteristics of American quarter horse from 6 months to 3 years, 3 years to 10 years and over 10 years

\begin{tabular}{lllll}
\hline Parameter & 6 moths to 3 years & 3 to 10 years & Over 10 years & $\mathrm{P}$ \\
\hline Heart rate $(\mathrm{bpm})$ & $55.31 \pm 13.18$ & $54.73 \pm 12.8$ & $47.26 \pm 13.62$ & 0.174 \\
P wave duration $(\mathrm{ms})$ & $134.95 \pm 26.19$ & $135.13 \pm 24.503$ & $142.07 \pm 24.28$ & 0.666 \\
P wave height $(\mathrm{mV})$ & $0.311 \pm 0.074$ & $0.369 \pm 0.052$ & $0.314 \pm 0.108$ & 0.089 \\
$\mathrm{P}_{1}$ wave height $(\mathrm{mV})$ & $0.1525 \pm 0.04782$ & $0.1670 \pm 0.07212$ & $0.1269 \pm 0.06343$ & 0.272 \\
$\mathrm{P}_{2}$ wave height $(\mathrm{mV})$ & $0.29 \pm 0.07$ & $0.34 \pm 0.06$ & $0.29 \pm 0.07$ & 0.141 \\
PR interval $(\mathrm{ms})$ & $259.89 \pm 49.76$ & $255.13 \pm 31.87$ & $283.60 \pm 41.34$ & 0.149 \\
QRS complex duration $(\mathrm{ms})$ & $110.53 \pm 19.77$ & $126.87 \pm 14.12$ & $136.13 \pm 15.26$ & 0.0002 \\
R wave height $(\mathrm{mV})$ & $0.13 \pm 0.07$ & $0.18 \pm 0.12$ & $0.29 \pm 0.52$ & 0.438 \\
S wave height $(\mathrm{mV})$ & $1.68 \pm 0.46$ & $1.76 \pm 0.62$ & $1.47 \pm 0.78$ & 0.431 \\
QT interval duration $(\mathrm{ms})$ & $428.16 \pm 73.02$ & $461.93 \pm 54.51$ & $447.53 \pm 0.74$ & 0.257 \\
$\mathrm{~T}_{1}$ wave height $(\mathrm{mV})$ & $0.75 \pm 0.40$ & $0.59 \pm 0.26$ & $0.51 \pm 0.27$ & 0.149 \\
$\mathrm{~T}_{2}$ wave height $(\mathrm{mV})$ & $0.29 \pm 0.20$ & $0.32 \pm 0.15$ & $0.40 \pm 0.40$ & 0.596 \\
ST interval deviation $(\mathrm{mV})$ & $0.27 \pm 0.19$ & $0.17 \pm 0.09$ & $0.17 \pm 0.08$ & 0.061 \\
\hline
\end{tabular}

$\mathrm{p}<0,05$ : significant statistical difference in Tukey test 


\section{CONCLUSION}

Given that in horses of the Quarter Horse breed sex does not influence the electrocardiographic parameters; only the duration of the QRS complex increases with the age of the animal.

\section{ACKNOWLEDGEMENTS}

To Fundação de Amparo à Pesquisa do Estado de Minas Gerais (FAPEMIG) and Conselho Nacional de Desenvolvimento Científico e Tecnológico (CNPq) for financial support.

\section{REFERENCES}

AYALA, I.; MONTES, A.; BERNAL, L.J. et al. Electrocardiographic values in Spanish-breed horses in different ages. Aust. Vet. J., v.72, p.225-226, 1995 .

AYALA, I.; MONTES, A.; PALACIO, M.J.F. et al. Aportaciones al estudio electrocardiográfico del caballo. An. Vet. (Murcia)., v.9, p.25-35, 1994.

BELGRAVE, J.O.S. A case of atrial fibrillation with congestive heart failure. Equine Vet. Educ., v.2, p.2-4, 1990.

CINTRA, A.G.C. O Cavalo: Características, Manejo e Alimentação. São Paulo: Roca, 2011. $384 \mathrm{p}$.

DINIZ, M.P.; MICHIMA, L.E.S.; FERNANDES, W.R. Estudo eletrocardiográfico de equinos de salto sadios. Pesq. Vet. Bras., v.31, p.355-361, 2011.

DINIZ, M.P.; MUZZI, R.A.L.; MUZZI, L.A.L. et al. Estudo eletrocardiográfico de equinos da raça Mangalarga Marchador. Arq. Bras. Med. Vet. Zootec., v.60, p.536-542, 2008.

FERNANDES, W.R.; LARSSON, M.H.M.A.; ALVES, A.L.G. et al. Características eletrocardiográficas em equinos clinicamente normais da raça Puro Sangue Inglês. Arq. Bras. Med. Vet. Zootec., v.56, p.143-149, 2004.
FREGIN, G.F. Medical evaluation of the cardiovascular system. Vet. Clin. North Am.: Equine Practice., v.8, p.329-346, 1992.

KING, C.M.; EVANS, D.L.; ROSE, R.J. Significance for exercise capacity of some electrocardiographic findings in racehorses. Aust. Vet. J., v.71, p.200-202, 1994.

MITTEN, L.A. Cardiovascular causes of exercise intolerance. Vet. Clin. North Am.: Equine Pract., v.12, p.473-494, 1996.

PATTESON, M.W. Equine cardiology. Blackwell Science:Oxford, 1996. 254p.

RAEKALLIO, M. Long term ECG recording with holter monitoring in clinically healthy horses. Acta Vet. Scand., v.33, p.71-75, 1992.

REEF, V.B. Cardiovascular ultrasonography. In:_. Equine veterinary ultrasound. Philadelphia: W. B. Saunders Company, 1998. p. $98-110$.

ROBERTSON, S.A. Electrocardiography for the equine practioner. Vet. Аппиа., v.132, p.192-200, 1992.

VERHEYEN, T.; DECLOEDT, A.; CLERCQ, D.D. et al. Electrocardiography in horses - part 1: how to make a good recording. Vla. Dierg. Tijds., v.79, p.331-336, 2010.

VINCENZI, R.C.; LARSSON, M.H.M.A.; FERNANDES, W.R. Parâmetros eletrocardiográficos em equinos clinicamente normais da raça Mangalarga. ParteIII. Amplitude e duração dos complexos e intervalos. Rev. Bras. Med. Vet., v.22, p.194-198, 2000.

YOUNG, L. Diseases of the heart and vessels. In: Hinchcliff K.W.; Kaneps A.J.; Geor R.J. Equine Sports Medicine and Surgery - Basic and Clinical Sciences of the Equine Athlete. Edinburgh: Elsevier Limited, 2004. p.728-767. 